\title{
Impact of extended lymphadenectomy on morbidity, mortality, recurrence and 5-year survival after gastrectomy for cancer. Meta-analysis of randomized clinical trials ${ }^{1}$
}

\author{
Impacto da linfadenectomia ampliada na morbidade, mortalidade, recidiva e cinco anos de \\ sobrevida após gastrectomia por câncer. Metanálise de ensaios clínicos randomizados
}

\author{
Suzana Angélica Silva Lustosa ${ }^{I}$, Humberto Saconato ${ }^{I I}$, Álvaro Nagib Atallah ${ }^{\mathrm{III}}$, Gaspar de Jesus Lopes Filho ${ }^{\mathrm{IV}}$, Delcio Matos ${ }^{\mathrm{V}}$

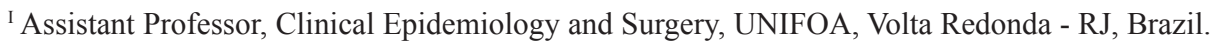 \\ ${ }^{\text {II }}$ Reviewer, Brazilian Cochrane Center, UNIFESP, Sao Paulo, Brazil. \\ III Full Professor, Internal Medicine, Dean of Postgraduate Studies, Director of Brazilian Cochrane Center of UNIFESP, Sao Paulo, Brazil. \\ IV Associate Professor, Chief, Gastroenterological Surgery Division, UNIFESP, Sao Paulo, Brazil. \\ ${ }^{v}$ Full Professor, Dean of Postgraduate Studies of Surgical Gastroenterological Division, UNIFESP, Sao Paulo, Brazil.
}

\begin{abstract}
Purpose: To compare morbidity, mortality, recurrence and 5-year survival between D1 and D2 or D3 for treatment of gastric cancer. Methods: Systematic review and meta-analysis of RCTs. Metaview in RevMan 4.2.8 for analysis; statistical heterogeneity by Cochran's $\mathrm{Q}$ test $(\mathrm{P}<0.1)$ and $\mathrm{I}^{2}$ test $(\mathrm{P}>50 \%)$. Estimates of effect were calculated using random effects model. Results: D2 or D3 was associated with higher in-hospital mortality, with $\mathrm{RR}=2.13, \mathrm{p}=0.0004,95 \% \mathrm{CI}, 1.40$ to $3.25, \mathrm{I}^{2}=0 \%, \mathrm{P}=0.63$; overall morbidity showed higher incidence in $\mathrm{D} 2$ or $\mathrm{D} 3, \mathrm{RR}=1.98, \mathrm{p}<0.00001,95 \% \mathrm{CI}, 1.64$ to $2.38, \mathrm{I}^{2}=33.9 \%, \mathrm{P}=0.20$; operating time showed longer duration in $\mathrm{D} 2$ or D3, weighted mean difference of $1.05, \mathrm{p}<0.00001,95 \% \mathrm{CI}, 0.71$ to $1.38, \mathrm{I}^{2}=78.7 \%, \mathrm{P}=0.03$, with significant statistical heterogeneity; reoperation showed higher rate in $\mathrm{D} 2$ or $\mathrm{D} 3$, with $\mathrm{RR}=2.33, \mathrm{p}<0.0001,95 \% \mathrm{CI}, 1.58$ to $3.44, \mathrm{I}^{2}=0 \%$, $\mathrm{P}=0.99$; hospital stay showed longer duration in the D2 or D3, with weighted mean difference of $4.72, \mathrm{p}<0.00001,95 \% \mathrm{CI}, 3.80$ to $5.65, \mathrm{I}^{2}=89.9 \%, \mathrm{P}<0.00001$; recurrence was analyzed showed lower rate in $\mathrm{D} 2$ or D3, with $\mathrm{RR}=0.89, \mathrm{p}=0.02,95 \% \mathrm{CI}, 0.80$ to $0.98, \mathrm{I}^{2}=71.0 \%, \mathrm{P}=0.03$, with significant statistical heterogeneity; mortality with recurrent disease showed higher incidence in $\mathrm{D} 1$, with $\mathrm{RR}=0.88, \mathrm{p}=0.04,95 \%$ CI, 0.78 to $0.99, \mathrm{I}^{2}=51.8 \%, \mathrm{P}=0.10 ; 5$-year survival showed no significant difference, with $\mathrm{RR}=1.05, \mathrm{p}=0.40,95 \% \mathrm{CI}, 0.93$ to 1.19 , $\mathrm{I}^{2}=49.1 \%$ and $\mathrm{P}=0.12$. Conclusions: $\mathrm{D} 2$ or D3 lymphadenectomy procedure is followed by higher overall morbidity and higher in-hospital mortality; D2 or D3 lymphadenectomy shows lower incidence of recurrence and lower mortality with recurrent disease, when analysed altogether with statistical heterogeneity; D2 or D3 lymphadenectomy has no significant impact on 5-year survival. Key words: Stomach Neoplasms. Lymph Node Excision. Meta-analysis. Clinical Trial. Prognosis.
\end{abstract}

\section{RESUMO}

Objetivo: Comparar a morbidade, mortalidade, recidiva e sobrevida de cinco anos entre linfadenectomia D1 e D2 ou D3 no tratamento do câncer gástrico. Métodos: Revisão sistemática metanálise de ensaios clínicos randomizados, programa Metaview, Revman 4.2.8. Heterogeneidade estatística pelo teste $\mathrm{Q}$ de Cochrane $(\mathrm{P}<0,1)$ e teste $\mathrm{I}^{2}(\mathrm{P}>50 \%)$. Estimativas dos efeitos pelo modelo randômico. Resultados: Maior mortalidade hospitalar em D2 ou D3, RR $=2.13, \mathrm{p}=0.0004,95 \% \mathrm{IC}, 1.40$ a 3.25, $\mathrm{I}^{2}=0 \%$, $\mathrm{P}=0.63$; maior morbidade geral em D2 ou D3, RR = 1.98, $\mathrm{p}<0.00001,95 \%$ IC, 1.64 a 2.38, $\mathrm{I}^{2}=33.9 \%, \mathrm{P}=0.20$; maior tempo operatório em $\mathrm{D} 2$ e $\mathrm{D} 3$, diferença de média ponderal de 1.05 , p $<0.00001,95 \%$ IC, 0.71 a $1.38, \mathrm{I}^{2}=78.7 \%, \mathrm{P}=0.03$; número de reoperações maior em $\mathrm{D} 2$ e $\mathrm{D} 3, \mathrm{RR}=2.33$, $\mathrm{p}<0.0001,95 \% \mathrm{IC}, 1.58$ a 3.44, $\mathrm{I}^{2}=0 \%, \mathrm{P}=0.99$; maior tempo de permanência hospitalar em $\mathrm{D} 2$ e $\mathrm{D} 3$, diferença de média ponderal de $4.72, \mathrm{p}<0.00001,95 \% \mathrm{IC}, 3.80$ a $5.65, \mathrm{I}^{2}=89.9 \%, \mathrm{P}<0.00001$; recidiva maior nos grupos D2 e D3, RR $=0.89, \mathrm{p}=0.02,95 \%$ IC, 0.80 a $0.98, \mathrm{I}^{2}=71.0 \%, \mathrm{P}=0.03$; mortalidade com doença recidivada maior em $\mathrm{D} 1, \mathrm{RR}=0.88, \mathrm{p}=0.04,95 \% \mathrm{IC}, 0.78$ a $0.99, \mathrm{I}^{2}=51.8 \%$, $\mathrm{P}=0.10 ; 5$ anos de sobrevida mostrou diferença estatística não significante, $\mathrm{RR}=1.05, \mathrm{p}=0.40,95 \% \mathrm{IC}, 0.93 \mathrm{a} 1.19, \mathrm{I}^{2}=49.1 \%$ e $\mathrm{P}=0.12$. Conclusões: Linfadenectomia D2 ou D3 está associada a maior morbidade e maior mortalidade intra-hospitalar; D2 ou D3 apresenta menor incidência de recidiva e menor mortalidade com recidiva, analisadas em conjunto, com heterogeneidade estatística; D2 ou D3 não tem impacto na sobrevida de 5 anos.

Descritores: Neoplasias Gástricas. Excisão de Linfonodo. Metanálise. Ensaio Clínico. Prognóstico.

${ }^{1}$ Research performed at Clinical Epidemiology Division, University Center of Volta Redonda (UNIFOA), Brazilian Cochrane Center, Division of Surgical Gastroenterological, Department of Surgery, Federal University of Sao Paulo (UNIFESP), Brazil. 


\section{Introduction}

Many aspects of the results from surgical treatment of gastric cancer remain controversial. Several observational studies have reported potential benefits from extended lymphadenectomy in terms of recurrence and 5-year survival, but randomized controlled trials have failed to confirm these results ${ }^{1,2,3,4,5}$. The theoretical advantage in extended lymph node resection, such that it increases the chances for curative treatment, might be illusory if it is considered that these nodes may not be involved in the disease. Moreover, by extending the node dissection, the surgical treatment may substantially increase the morbidity and mortality $6,7,8$

Therefore the presumed therapeutic benefit of extended lymphadenectomy remains to be proven and a systematic review and meta-analysis of homogeneous randomized controlled trials could give the answer in terms of the best available scientific evidence so far. We undertook this study in order to analyze the existing evidence and to provide a meta-analysis of morbidity, mortality, recurrence and 5-year survival parameters.

\section{Methods}

The logistics and the design for this study were prepared according to Cochrane Collaboration methodology and approved by the UNIFESP-Escola Paulista de Medicina Cochrane Meta-analysis Unit, Sao Paulo, Brazil. The writing and interpreting of reports for this systematic review was based on the Quality of Reporting of Meta-analysis (QUORUM) group statement, using a 17 -item checklist for reporting systematic reviews ${ }^{9}$.

\section{Search strategy for identification of studies}

The following bibliographic databases were searched in order to identify randomized controlled trials (RCTs): Cochrane Central Register of Controlled Trials, MEDLINE, EMBASE, LILACS, Science Citation Index and Ovid journals. The references of the RCTs identified were checked to complete the electronic searches, without limitation on date or language. Abstracts of possibly relevant papers were identified and, after reaching a consensus in the reviewers' analysis, such articles were retrieved in full.

The search strategy in Medline (PubMed) was based on medical subject heading terms $(\mathrm{MeSH})$, text words and Boolean operators such as 'AND', 'OR' and 'NOT', which were used in succession; the following subject terms with appropriate combinations were used: Search 1 - dissection, nodal dissection, resection, $\mathrm{r} 1$ gastrectomy, r2 gastrectomy, $\mathrm{d} 1$ dissection, $\mathrm{d} 2$ dissection, $\mathrm{d} 3$ dissection, $\mathrm{r} 3$ gastrectomy and lymphadenectomy; Search 2 - gastric neoplasms, gastric carcinoma, gastric cancer and stomach neoplasms; Search 3 randomized controlled trials, controlled clinical trials, doubleblind methods, placebos, research design, comparative study, evaluation studies, follow-up studies, prospective studies, animals and cross-over studies; Search 4-search 1, 2 and 3. A cross-reference search for review articles in leading journals was conducted.

\section{Study selection and data extraction}

All RCTs comparing D1 vs. D2 and D1 vs. D3 were included for evaluation of methodological quality. Data were extracted using a pre-designed form. The methodological quality of the studies was assessed on the basis of pre-specified characteristics: the method of the research, the participants, the standardization of the interventions, the outcome measurements and the standardization of pathological examinations. The randomization procedure was analyzed in terms of the method used to generate the random allocation sequence, the explanation of the allocation concealment and the method of implementing the allocation sequence ${ }^{10}$.

Each trial was assessed by two reviewers (SASL and $\mathrm{DM}$ ), independently and without blinding, in order to evaluate whether the trial should be included or not. Disagreements were resolved by consensus. The basis for the methodological evaluation was the randomization procedure, sample size calculation, description of the eligibility criteria, intention-to-treat analysis, standardization of the surgical procedure and standardization of pathological examination. The data on the included and excluded studies were extracted and detailed in tables. The clinical heterogeneity between the included studies was discussed by all authors of this systematic review.

\section{Analysis}

Statistical analysis were carried out by entering the extracted data into Metaview in RevMan 4.2.8 software (Cochrane Collaboration, Oxford, UK) and the relative risk (RR) or weighted mean difference (WMD) was calculated for each outcome. When the model assumed that there was no heterogeneity between individual trials, fixed effects models (Mantel-Haenszel and Peto methods) were used. If statistical heterogeneity was incorporated, a random effects model (DerSimonian-Laird method) was used ${ }^{11}$.

The degree of statistical homogeneity between the studies was assessed by using the modified $\boldsymbol{N}^{2}$ test (Cochran's Q) which, by convention, indicates the presence of heterogeneity when $\mathrm{P}>0.1$. When a small number of trials were included in the meta-analysis the $\mathrm{I}^{2}$ test was used, which is considered statistically significant if $50 \%$ or greater.

A cutoff of $\mathrm{p}<0.05$ was required for the overall relative risk $(\mathrm{RR})$ or weighted mean difference (WMD) to be deemed statistically significant. Results relating to intervention effects were presented using forest plot graphs. Number needed to harm (NNH) was calculated and sensitivity analysis adjusted for methodological quality was performed.

The sensitivity analysis was done by excluding or including studies that appeared to be outliers. If studies seemed to be heavily affecting the results they were excluded and the analysis was repeated without them.

\section{Results}

\section{Included studies}

All RCTs published as original studies, citing D1 versus D2 or D1 versus D3 lymphadenectomy as a primary treatment for 
gastric cancer with curative intent, up to the end of May 2007, were considered. Special attention was given to systematic review and meta-analysis with the same objective. Abstracts were not included.

The systematic electronic search of the literature identified 51 abstracts, which were subjected to a screening process resulting in 9 full articles; 4 of these articles did not fulfill the inclusion criteria, which made it possible to select 5 randomized controlled trials ( 9 reports). Three trials ${ }^{12,13,14}$ were national multicenter studies from the Netherlands, UK and Italy respectively; two studies ${ }^{5,15}$ were done at single institutions in China and Taiwan respectively.

Three of the selected trials compared D1 vs. D2 $2^{12,13,14}$ and two trials compared D1 vs. D3 ${ }^{5,15}$. These studies involved 1549 patients, of whom 791 were allocated to the D1 surgical procedure, 617 to D2 and 141 to D3.

A systematic review was conducted by McCulloch et $a l .{ }^{6}$, in 2005 , including randomized and non-randomized comparisons between D1 and D2 gastrectomy for primary treatment of gastric cancer. The meta-analysis was performed separately; ${ }^{15}$ separate studies were selected, comprising two randomized trials, two non-randomized comparisons and 11 cohort studies reporting results from one technique only.

The main study characteristics and items of methodological quality, outcome measurements and sample sizes of the included studies are shown in Table1.

TABLE 1 - Characteristics of the RCTs included in the review

\begin{tabular}{|c|c|c|c|c|c|}
\hline STUDY REFERENCE & AIM & METHODOLOGICAL QUAL & LITY & OUTCOMES & Sample \\
\hline ROBERTSON, 1994 & D1 x D3 & $\begin{array}{l}\text { RANDOMIZATION PROCEDURE } \\
\text { SAMPLE SIZE CALCULATION } \\
\text { ELEGIBILITY CRITERIA DESCRIBED } \\
\text { INTENTION-TO-TREAT ANALYSIS } \\
\text { SURGERY STANDARDIZATION } \\
\text { PATHOLOGIC STANDARDIZATION } \\
\text { STAGE OF DISEASE } \\
\text { SURGEON EXPERIENCE }\end{array}$ & $\begin{array}{l}\text { Adequate } \\
- \\
\text { YES } \\
- \\
\text { YES } \\
\text { YES } \\
\text { T1, T2, T3, T4 } \\
\text { YES }\end{array}$ & $\begin{array}{l}\text { OVERALL MORBIDITY } \\
\text { IN-HOSPITAL MORTALITY } \\
\text { MORTALITY WITH } \\
\text { RECURRENCE } \\
\text { INTRA-ABDOMINAL } \\
\text { INFECTION } \\
\text { HOSPITAL STAY } \\
\text { OPERATING TIME } \\
\text { REOPERATION } \\
\text { 5-YEAR SURVIVAL }\end{array}$ & $\begin{array}{l}\text { D1 }=25 \\
\text { D3 }=30\end{array}$ \\
\hline CUSCHIERI, 1996, 1999 & D1 X D2 & $\begin{array}{l}\text { RANDOMIZATION PROCEDURE } \\
\text { SAMPLE SIZE CALCULATION } \\
\text { ELEGIBILITY CRITERIA DESCRIBED } \\
\text { INTENTION-TO-TREAT ANALYSIS } \\
\text { SURGERY STANDARDIZATION } \\
\text { PATHOLOGIC STANDARDIZATION } \\
\text { STAGE OF DISEASE } \\
\text { SURGEON EXPERIENCE }\end{array}$ & $\begin{array}{l}\text { Adequate } \\
\text { YES } \\
\text { YES } \\
\text { YES } \\
\text { JRSCG } \\
\text { UICC } \\
\text { T1, T2, T3 } \\
-\end{array}$ & $\begin{array}{l}\text { OVERALL MORBIDITY } \\
\text { IN-HOSPITAL MORTALITY } \\
\text { MORTALITY WITH } \\
\text { RECURRENCE } \\
\text { CARDIAC MORBIDITY } \\
\text { PULMONARY MORBIDITY } \\
\text { TROMBOEMBOLIC } \\
\text { MORBIDITY } \\
\text { HOSPITAL STAY } \\
\text { RECURRENCE } \\
\text { 5-YEAR SURVIVAL }\end{array}$ & $\begin{array}{l}\mathrm{D} 1=200 \\
\mathrm{D} 2=200\end{array}$ \\
\hline BONENKAMP,1995,1999 & $\mathrm{D} 1 \times \mathrm{D} 2$ & $\begin{array}{l}\text { RANDOMIZATION PROCEDURE } \\
\text { SAMPLE SIZE CALCULATION } \\
\text { ELEGIBILITY CRITERIA DESCRIBED } \\
\text { INTENTION-TO-TREAT ANALYSIS } \\
\text { SURGERY STANDARDIZATION } \\
\text { PATHOLOGIC STANDARDIZATION } \\
\text { STAGE OF DISEASE } \\
\text { SURGEONS EXPERIENCE }\end{array}$ & $\begin{array}{l}\text { Adequate } \\
\text { YES } \\
\text { YES } \\
\text { YES } \\
\text { JRSGC } \\
\text { JRSGC } \\
\text { T1,T2,T3,T4,Tx } \\
\text { YES }\end{array}$ & $\begin{array}{l}\text { OVERALL MORBIDITY } \\
\text { IN-HOSPITAL MORTALITY } \\
\text { MORTALITY WITH } \\
\text { RECURRENCE } \\
\text { WOUND INFECTION } \\
\text { INTRA-ABDOMINAL } \\
\text { INFECTION } \\
\text { PANCREATIC LEAKAGE } \\
\text { ANASTOMOTIC LEAKAGE } \\
\text { CARDIAC MORBIDITY } \\
\text { PULMONARY MORBIDITY } \\
\text { TROMBOEMBOLIC } \\
\text { MORBIDITY } \\
\text { REOPERATION } \\
\text { HOSPITAL STAY } \\
\text { RECURRENCE } \\
\text { 5-YEAR SURVIVAL }\end{array}$ & $\begin{array}{l}\mathrm{D} 1=380 \\
\mathrm{D} 2=331\end{array}$ \\
\hline DEGIULI, 1998 & $\mathrm{D} 1 \times \mathrm{D} 2$ & $\begin{array}{l}\text { RANDOMIZATION PROCEDURE } \\
\text { SAMPLE SIZE CALCULATION } \\
\text { ELEGIBILITY CRITERIA DESCRIBED } \\
\text { INTENTION-TO-TREAT ANALYSIS } \\
\text { SURGERY STANDARDIZATION } \\
\text { PATHOLOGIC STANDARDIZATION } \\
\text { STAGE OF DISEASE } \\
\text { SURGEON EXPERIENCE }\end{array}$ & $\begin{array}{l}\text { Adequate } \\
\text { YES } \\
\text { YES } \\
\text { - } \\
\text { JRSGC } \\
\text { JRSGC } \\
\text { T1, T2, T3 } \\
\text { YES }\end{array}$ & $\begin{array}{l}\text { OVERALL MORBIDITY } \\
\text { IN-HOSPITAL MORTALITY } \\
\text { INTRA-ABDOMINAL } \\
\text { INFECTION } \\
\text { PANCREATIC LEAKAGE } \\
\text { CARDIAC MORBIDITY } \\
\text { PULMONARY MORBIDITY } \\
\text { REOPERATION } \\
\text { HOSPITAL STAY }\end{array}$ & $\begin{array}{l}\mathrm{D} 1=76 \\
\mathrm{D} 2=86\end{array}$ \\
\hline WU, 2004, 2006 & D1 $x$ D3 & $\begin{array}{l}\text { RANDOMIZATION PROCEDURE } \\
\text { SAMPLE SIZE CALCULATION } \\
\text { ELEGIBILITY CRITERIA DESCRIBED } \\
\text { INTENTION-TO-TREAT ANALYSIS } \\
\text { SURGERY STANDARDIZATION } \\
\text { PATHOLOGIC STANDARDIZATION } \\
\text { STAGE OF DISEASE } \\
\text { SURGEON EXPERIENCE }\end{array}$ & $\begin{array}{l}\text { Adequate } \\
\text { YES } \\
\text { YES } \\
- \\
\text { JRSGC } \\
\text { JRSGC } \\
\text { T1, T2, T3, T4 } \\
\text { YES }\end{array}$ & $\begin{array}{l}\text { OVERALL MORBIDITY } \\
\text { IN-HOSPITAL MORTALITY } \\
\text { MORTALITY WITH } \\
\text { RECURRENCE } \\
\text { WOUND INFECTION } \\
\text { INTRA-ABDOMINAL } \\
\text { INFECTION } \\
\text { PANCREATIC LEAKAGE } \\
\text { ANASTOMOTIC LEAKAGE } \\
\text { CARDIAC MORBIDITY } \\
\text { OPERATING TIME } \\
\text { REOPERATION } \\
\text { HOSPITAL STAY } \\
\text { 5-YEAR SURVIVAL }\end{array}$ & $\begin{array}{l}\mathrm{D} 1=110 \\
\mathrm{D} 3=111\end{array}$ \\
\hline
\end{tabular}

JRSGC - Japanese Society for Research in Gastric Cancer UICC - International Union Against Cancer RCT - Randomized controlled trials 


\section{Methodological quality of the included studies}

The randomization procedure was described in all the included studies. It was regarded as very good in all trials except one $^{5}$, in which it was considered adequate since this trial did not explain the method used for implementing the random allocation and whether the allocation concealment was maintained until the interventions were assigned.

The underlying sample size calculation was described in four studies, while one trial ${ }^{5}$ did not justify how the number of patients that entered the study was determined. In the Dutch trial ${ }^{12}$, the calculated sample size was based on an expected five-year survival rate of $20 \%$ for patients undergoing D1 dissection with curative intent and 32\% for those undergoing surgery with D2 dissection with curative intent; in the Chinese trial ${ }^{17}$ the sample size calculation was based on an expected 5-year survival rate of $20 \%$ with D1 dissection and $40 \%$ for those allocated to D3 dissection ( $\mathrm{Wu} 2006)$; in the Italian trial ${ }^{14}$ the size of the study was calculated on the basis of the effects on 5-year survival rate, from $30 \%$ after D1 to $45 \%$ after D2 surgery; in the UK trial ${ }^{3}$ the sample size was calculated based on a improvement of 5-year survival from $20 \%$ in the D 1 procedure to $34 \%$ in the D2 procedure.

The eligibility criteria for participants and the settings were described in all trials. Eligible patients had to have histologically proven gastric adenocarcinoma that was potentially curable, and physical fitness suitable for elective operation of either type of lymphadenectomy. The upper age limit for entering the studies was variable, ranging from 75 to 85 years ${ }^{4,17}$. Patients with esophageal involvement, previous chemotherapy or radiotherapy or previous coexisting cancer were excluded. In all trials the patient was finally eligible to enter the trial when, in the staging laparotomy, the tumor could be excised and if a safe margin for radical subtotal or total gastrectomy could be obtained. Biopsies and frozen sections of enlarged lymph nodes were obtained in the staging laparotomy in 4 trials $^{3,4,14,15}$. The analysis of the outcome measurements was performed on an intention-to-treat basis in only two trials ${ }^{3,4}$.

The JRSCG (Japanese Society for Research in Gastric Cancer) provided guidelines for the standardization of surgical treatment in 4 trials $^{3,4,14,15}$ and standardization of pathological evaluation in 3 trials $^{3,4,14}$. The UICC (International Union Against Cancer) provided the pathological standardization in one trial ${ }^{3}$. In one trial ${ }^{5}$ the operative procedures and the processing of the specimens were described but no reference was reported.

With regard to disease staging, two trials included patients in the T1, T2 and T3 pathological stages ${ }^{3,15}$ and three trials included patients in the $\mathrm{T} 1$, T2, T3 and T4 pathological stages $^{3,4,5}$.
All the surgeons involved in four included trials $\mathrm{s}^{3,4,14,15}$ were trained and supervised the procedures. The quality control was well described in 4 trials $\mathrm{s}^{3,45,14}$, in which the participating surgeons had been specially trained for D2 dissection and for supervising the technique and the extent of lymph-node dissection; after the operation, the perigastric tissue was divided into the proper lymph-node stations and the number and location of nodes were detected at pathological examination in accordance with the protocol guidelines ${ }^{4}$.

\section{Excluded studies}

Only one randomized controlled trial was excluded from this systematic review for not fulfilling the inclusion criteria. This excluded study which was published in 1988 reported 3 years of follow-up time ${ }^{8}$.

\section{Meta-analysis results}

\section{$\underline{\text { In-hospital mortality }}$}

In-hospital mortality, which was analyzed in 5 studies that included 1549 patients, of whom 617 D2 vs 656 D1 and 141 D3 vs 135 D1 patients, showed a significantly higher rate in the D2 (RR, 2.12; 95\% CI, 1.39 to 3.25; $\mathrm{p}=0.0005)$ with no significant statistical data heterogeneity $\left(\mathrm{P}=0.42, \mathrm{I}^{2}=0 \%\right)$ and a not significant difference in the D3 lymphadenectomy group (RR, 2.52; CI, 95\%, 0.11 to $59.18 ; \mathrm{p}=0.57)^{5,12,13,14,15}$.

The overall effect estimate of 758 D2/D3 versus 791 D1 patients revealed significantly higher in-hospital mortality rate $(\mathrm{RR}, 2.13 ; 95 \% \mathrm{CI}, 1.40$ to $3.25 ; \mathrm{p}=0.0004)$ with no significant statistical data heterogeneity $\left(\mathrm{P}=0.63\right.$ and $\left.\mathrm{I}^{2}=0 \%\right)$. The meta-analysis result from this outcome measurement is shown in Figure 1.

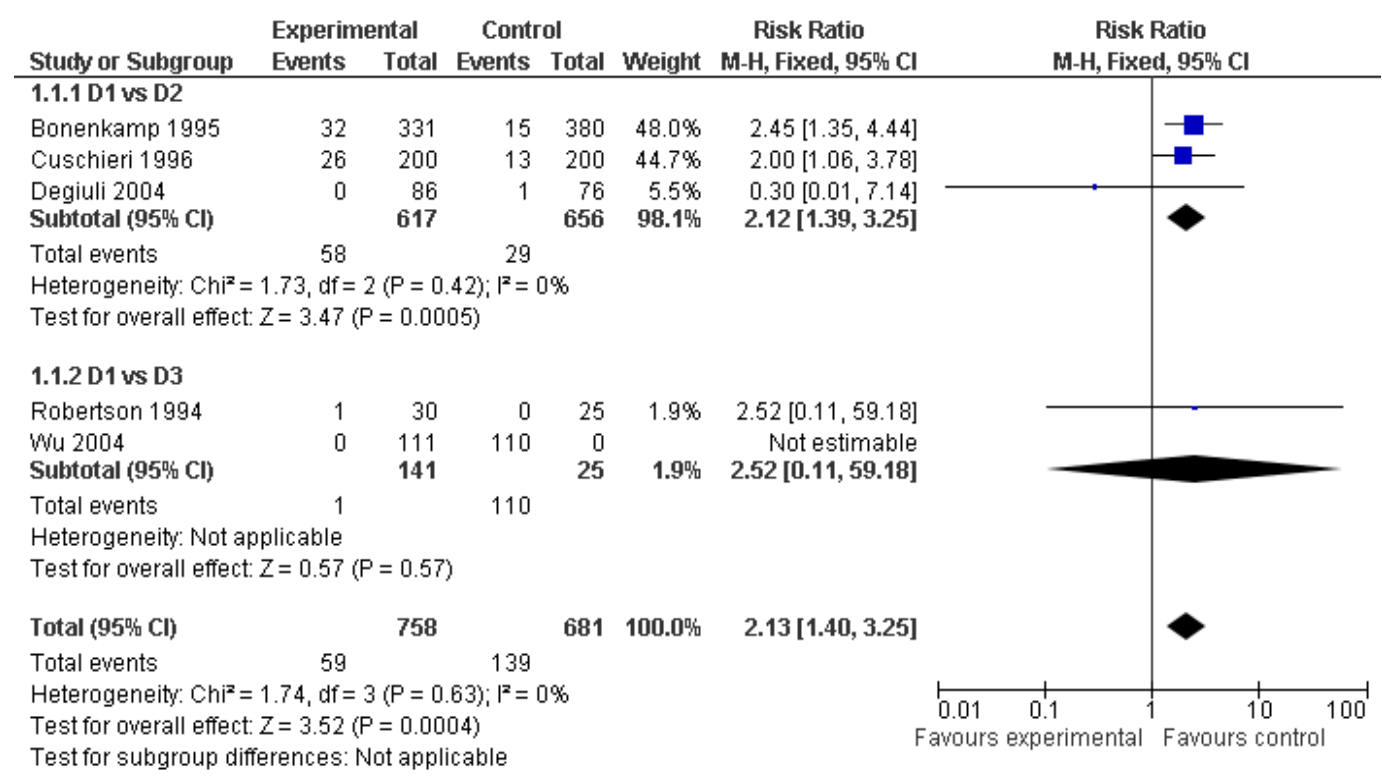

FIGURE 1 - Meta-analysis of in-hospital mortality rate. Effects estimates (odds ratio; 95\% CI). Pooled treatment effect is shown as a diamond that spans the $95 \%$ CI. No statistical heterogeneity between studies results. Overall effect with significant statistical difference favouring D1 lymphadenectomy $(p=0,00004)$ 


\section{Overall morbidity}

Overall morbidity, which was analyzed in 5 studies that included 1549 patients, of whom $617 \mathrm{D} 2$ vs $656 \mathrm{D} 1$ and 141 D3 vs 135 D1 patients, showed both a significantly higher rate in the $\mathrm{D} 2$ (RR, 1.83; $95 \% \mathrm{CI}, 1.51$ to $2.21 ; \mathrm{p}<0.00001$ ) with no statistical data heterogeneity $\left(\mathrm{P}=0.46, \mathrm{I}^{2}=0 \%\right)$ and in the D3 lymphadenectomy group (RR, 4.07; 95\% CI, 1.96 to $8.43 ; p=0.0002$ ) with statistical data heterogeneity $\left(\mathrm{P}=0.05, \mathrm{I}^{2}=74 \%\right)$.

The overall effect estimate of 758 D2/D3 versus 791 D 1 patients revealed significantly higher overall morbidity rate (RR, 1.98; 95\% CI; 1.64 to $2.38, p<0.00001$ ) with no significant statistical data heterogeneity $(\mathrm{P}=0.20$ and $\mathrm{I}^{2}=33.9 \%$ ). The meta-analysis result from this outcome measurement is shown in Figure 2.

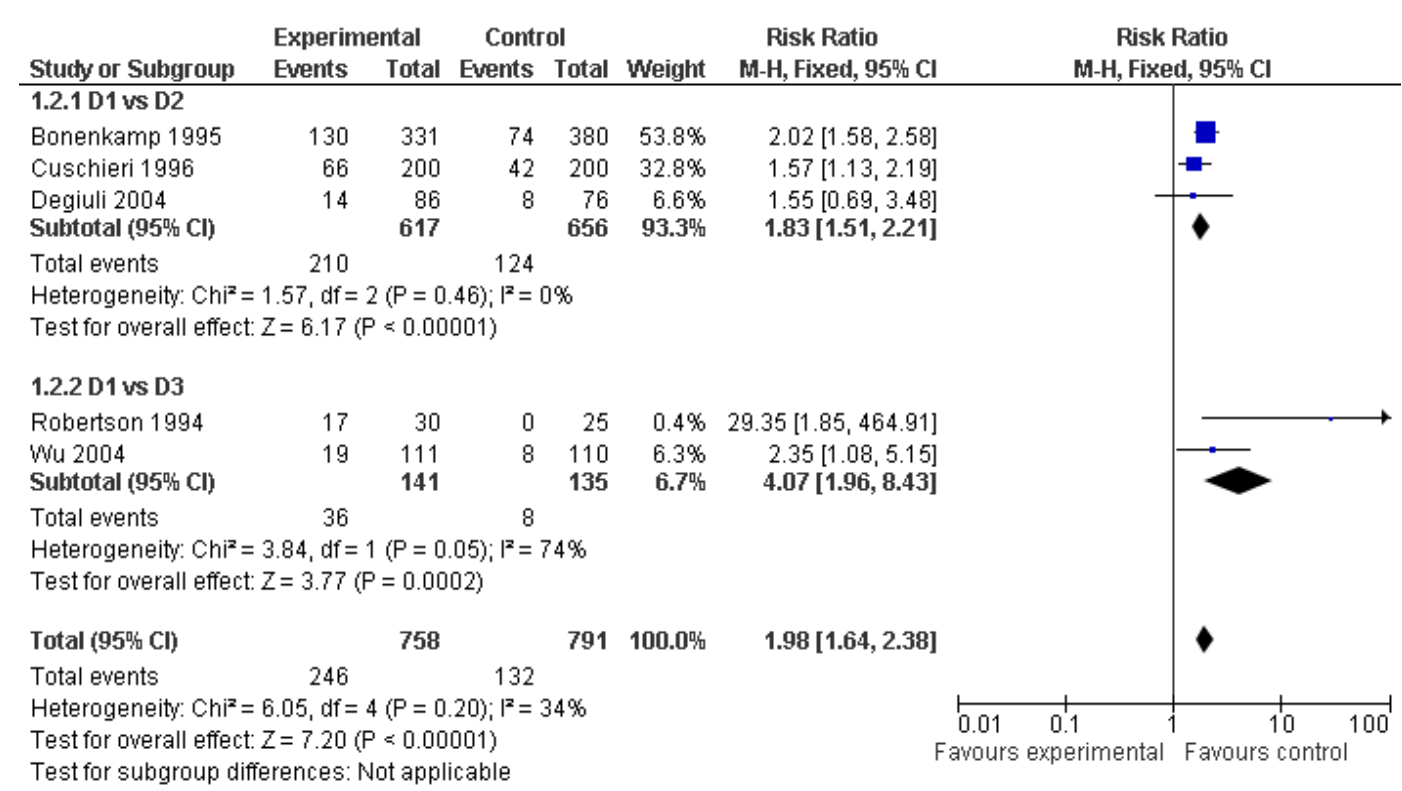

FIGURE 2 - Meta-analysis of overall morbidity. Effects estimates (odds ratio; 95\% CI). Pooled treatment effect is shown as a diamond that spans the $95 \%$ CI. No statistical heterogeneity between D1 x D2 studies results. Overall effect with significant statistical difference favouring D1 lymphadenectomy $(\mathrm{p}<0,00001)$

\section{Morbidity parameters}

The results for all the morbidity parameters analyzed favored D1 over D2 or D3 lymphadenectomy, with a statistically significant difference, except for thromboembolic mortality. The summary of the meta-analysis results relating to the morbidity parameters of wound infection, intra-abdominal infection, anastomotic leakage, cardiac morbidity, pulmonary morbidity and thromboembolic morbidity are shown in Table 2.

TABLE 2 - Summary of the meta-analysis results of morbidity parameters

\begin{tabular}{|c|c|c|c|c|c|c|}
\hline Outcome Measures & Studies & Sample Size & $\begin{array}{c}\text { Statistical } \\
\text { Method }\end{array}$ & Effect Size & Heterogeneity & $p$ value \\
\hline $\begin{array}{l}\text { Anastomotic } \\
\text { Leakage }\end{array}$ & $\begin{array}{l}\text { Bonenkamp } 1995 \\
\text { Wu } 2004\end{array}$ & $\begin{array}{c}\mathrm{D} 1=490 \\
\mathrm{D} 2 \text { or } \mathrm{D} 3=442\end{array}$ & $\begin{array}{l}\text { RR (fixed) } \\
\text { Cl } 95 \%\end{array}$ & $2.44(1.38,4.31)$ & $\begin{array}{l}P=0.27 \\
I^{2}=17,3 \%\end{array}$ & $\begin{array}{l}0,002^{*} \\
\text { Favours D1 }\end{array}$ \\
\hline Wound Infection & $\begin{array}{l}\text { Bonenkamp } 1995 \\
\text { Wu } 2004\end{array}$ & $\begin{array}{c}\mathrm{D} 1=490 \\
\mathrm{D} 2 \text { or } \mathrm{D} 3=442\end{array}$ & $\begin{array}{l}\text { RR(fixed) } \\
\text { Cl } 95 \%\end{array}$ & $2.32(1.32,4.08)$ & $\begin{array}{l}P=0.93 \\
I^{2}=0 \%\end{array}$ & $\begin{array}{c}0,003^{*} \\
\text { Favours D1 }\end{array}$ \\
\hline $\begin{array}{l}\text { Intra-abdominal } \\
\text { infection }\end{array}$ & $\begin{array}{l}\text { Bonenkamp } 1995 \\
\text { Robertson } 1994 \\
\text { De Giuli } 2004 \\
\text { Wu } 2004\end{array}$ & $\begin{array}{c}D 1=591 \\
D 2 \text { or } D 3=558\end{array}$ & $\begin{array}{l}\text { RR (fixed) } \\
\text { CI 95\% }\end{array}$ & $2.84(1.91,4.23)$ & $\begin{array}{l}P=0,11 \\
I^{2}=50,5 \%\end{array}$ & $\begin{array}{l}0,00001^{*} \\
\text { Favours D1 }\end{array}$ \\
\hline Cardiac Morbidity & $\begin{array}{l}\text { Robertson } 1994 \\
\text { Bonenkamp } 1995 \\
\text { Cushieri } 1996 \\
\text { De Giuli } 2004 \\
\text { Wu } 2004\end{array}$ & $\begin{array}{c}\mathrm{D} 1=766 \\
\mathrm{D} 2 \text { or } \mathrm{D} 3=728\end{array}$ & $\begin{array}{l}\text { RR (fixed) } \\
\text { CI 95\% }\end{array}$ & $1.55(0.87,2.75)$ & $\begin{array}{c}\mathrm{I}^{2}=18,8 \% \\
\mathrm{P}=0.30\end{array}$ & 0,14 \\
\hline $\begin{array}{l}\text { Pulmonary } \\
\text { Morbidity }\end{array}$ & $\begin{array}{l}\text { Bonenkamp } 1995 \\
\text { Cushieri } 1996 \\
\text { De Giuli } 2004 \\
\text { Wu } 2004\end{array}$ & $\begin{array}{c}\mathrm{D} 1=656 \\
\mathrm{D} 2 \text { or } \mathrm{D} 3=617\end{array}$ & $\begin{array}{l}\text { RR (fixed) } \\
\text { CI 95\% }\end{array}$ & $2.25(1.48,3.42$ & $\begin{array}{l}I^{2}=0 \% \\
P=0.75\end{array}$ & $\begin{array}{l}0,0002^{*} \\
\text { Favours D1 }\end{array}$ \\
\hline $\begin{array}{l}\text { Trombo-Embolic } \\
\text { Morbidity }\end{array}$ & $\begin{array}{l}\text { Bonenkamp } 1995 \\
\text { Cushieri } 1996\end{array}$ & $\begin{array}{c}D 1=580 \\
D 2 \text { or } D 3=531\end{array}$ & $\begin{array}{l}\text { RR (fixed) } \\
\text { Cl } 95 \%\end{array}$ & $2.96(0.80,11.00)$ & $\begin{array}{l}I^{2}=0 \% \\
P=0.39\end{array}$ & 0,10 \\
\hline
\end{tabular}

$$
\begin{aligned}
& \mathrm{RR}=\text { Relative risk } \\
& \mathrm{P}=\text { Heterogeneity index }
\end{aligned}
$$

$\mathrm{CI}=$ Confidence interval

$\mathrm{p}=$ test for overall effect
$\mathrm{I}^{2}=$ Heterogeneity index

* = statistically significant 


\section{Operating time, reoperation and hospital stay}

Operating time, which was analyzed in 2 studies that included 276 patients, of whom 30 D2 vs 25 D1 and 111 D3 vs $110 \mathrm{D} 1$ patients, showed both a significantly higher rate in the D2 (WMD, 2.00; 95\%CI, 1.07 to 2.93 ) and in the D3 lymphadenectomy group (WMD, 1.05; 95\% CI, 0.54 to 1.26$)^{5,15}$. The overall effect estimate of 141 D2/D3 versus 135 D1 patients revealed significantly longer operating time (WMD, 1.05; $95 \% \mathrm{CI} ; 0.71$ to $1.38, \mathrm{p}<0.00001)$ with significant statistical data heterogeneity $\left(\mathrm{P}=0.03\right.$ and $\left.\mathrm{I}^{2}=78.7 \%\right)$. The meta-analysis result from this outcome measurement is shown in Figure 3.

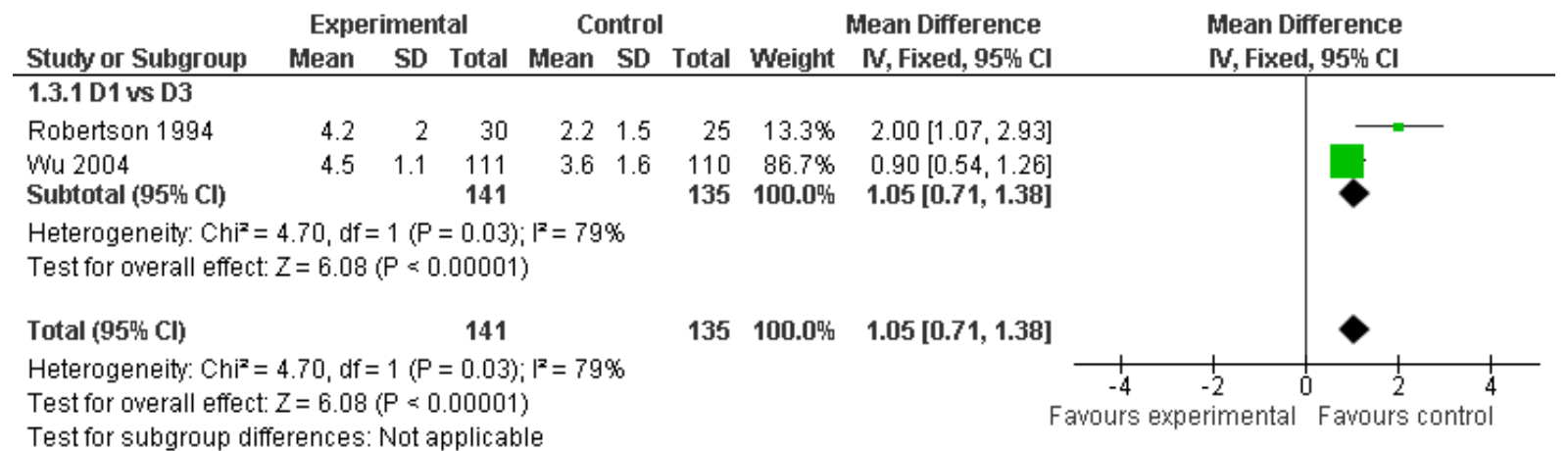

FIGURE 3 - Meta-analysis of operating time (hours). Effects estimates (odds ratio; 95\% CI). Pooled treatment effect is shown as a diamond that spans the $95 \%$ CI. Significant statistical heterogeneity between studies results. Overall effect with significant statistically signigicant difference between D1 and D3 lymphadenectomy favoring D1 ( $<<0,00001)$

Reoperation rate, which was analyzed in 4 studies that included 1149 patients, of whom 417 D2 vs 456 D1 and 141 D3 vs $135 \mathrm{D} 1$ patients, showed a significantly higher rate in the D2 (RR, $2.27 ; 95 \% \mathrm{CI}, 1.51$ to $3.41 ; \mathrm{p}<0.0001$ ) with no statistical data heterogeneity $\left(\mathrm{P}=0.89, \mathrm{I}^{2}=0 \%\right)$ and a no significant difference in the D3 lymphadenectomy group (RR, 2.93; 95\% CI, 0.76 to $11.21 ; \mathrm{p}=0.12)$ with no statistical data heterogeneity $(\mathrm{P}=0.99$,
$\left.\mathrm{I}^{2}=0 \%\right)^{5,12,13,15}$

The overall effect estimate of 558 D2/D3 versus 591 D1 patients revealed significantly higher in-hospital reoperation rate $(\mathrm{RR}, 2.33 ; 95 \% \mathrm{CI} ; 1.58$ to $3.44, \mathrm{p}<0.0001)$ with no significant statistical data heterogeneity $\left(\mathrm{P}=0.99\right.$ and $\left.\mathrm{I}^{2}=0 \%\right)$. The meta-analysis result from this outcome measurement is shown in Figure 4.

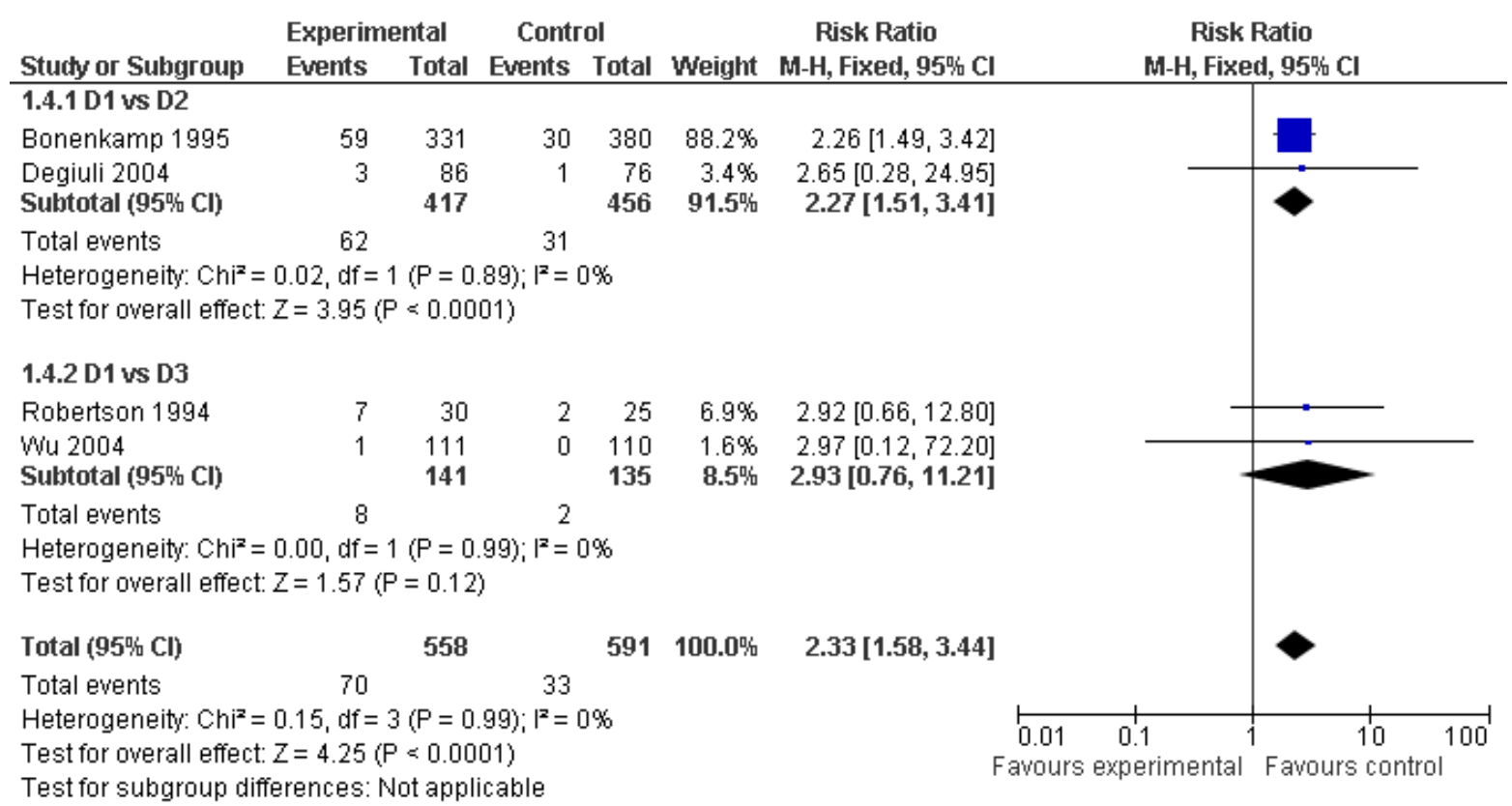

FIGURE 4 - Meta-analysis of reoperation. Effects estimates (odds ratio; 95\% CI). Pooled treatment effect is shown as a diamond that spans the $95 \%$ CI. No significant statistical heterogeneity between studies results. Overall effect with statistically significant difference between D1 and D2 or D3 lymphadenectomy favoring D1 $(\mathrm{p}<0.0001)$ 
Hospital stay, which was analyzed in 5 studies that included 1548 patients, of whom 617 D2 vs 655 D1 and 141 D3 vs $135 \mathrm{D} 1$ patients, showed both a significantly higher rate in the D2 (WMD, 4.38; 95\%CI, 3.34 to 5.42;p $<0.00001$ ) with statistical data heterogeneity $\left(\mathrm{P}<0.00001, \mathrm{I}^{2}=94.3 \%\right)$ and a significantly higher difference in the D3 lymphadenectomy group (WMD, 6.04; $95 \%$ CI, 4.00 to $8.09 ; \mathrm{p}<0,00001)$ with statistical data heterogeneity
$\left(\mathrm{P}=0.11, \mathrm{I}^{2}=61.6 \%\right)^{5,12,13,14,15}$.

The overall effect estimate of 758 D2/D3 versus 790 D1 patients revealed significantly longer hospital stay (WMD, 4.72; $95 \% \mathrm{CI} ; 3.80$ to $5.65, \mathrm{p}<0.00001)$ with significant statistical data heterogeneity $\left(\mathrm{P}<0,00001\right.$ and $\left.\mathrm{I}^{2}=89.9 \%\right)$. The meta-analysis result from this outcome measurement is shown in Figure 5.

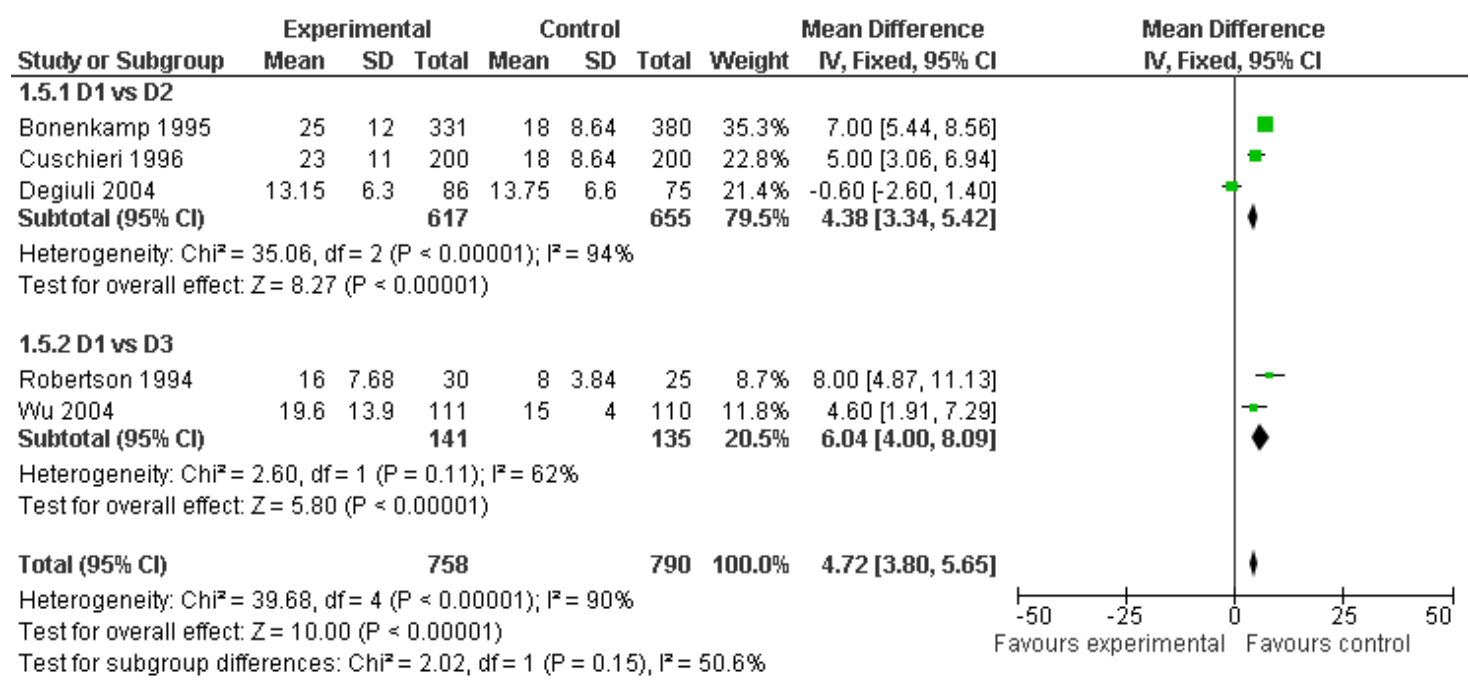

FIGURE 5 - Meta-analysis of hospital stay (days). Effects estimates (odds ratio; 95\% CI). Pooled treatment effect is shown as a diamond that spans the $95 \%$ CI. Significant statistical heterogeneity between studies results. Overall effect with statistically significant difference between D1 and D2 or D3 lymphadenectomy favoring D1 ( $p=0.00001)$

\section{Recurrence}

Recurrence rate, which was analyzed in 3 studies that included 1332 patients, of whom 531 D2 vs 580 D1 and 111 D3 vs $110 \mathrm{D} 1$ patients, showed a no significant difference in the D2 (RR, $0.91 ; 95 \% \mathrm{CI}, 0.82$ to $1.01 ; \mathrm{p}=0.08)$ with statistical data heterogeneity $\left(\mathrm{P}=0.03, \mathrm{I}^{2}=78.8 \%\right)$ and a no significant difference in the D3 lymphadenectomy group (RR, 0.76 ; 95\% CI, 0.57 to

\section{$11.21 ; \mathrm{p}=1.02)^{5,12,15}$.}

The overall effect estimate of 642 D2/D3 versus 690 D1 patients revealed significantly higher recurrence rate in the D1 lymphadenectomy group (RR, 0.89 ; $95 \% \mathrm{CI} ; 0.80$ to $0.98, \mathrm{p}<0.02$ ) with significant statistical data heterogeneity $\left(\mathrm{P}=0.03\right.$ and $\left.\mathrm{I}^{2}=71 \%\right)$. The meta-analysis result from this outcome measurement is shown in Figure 6.

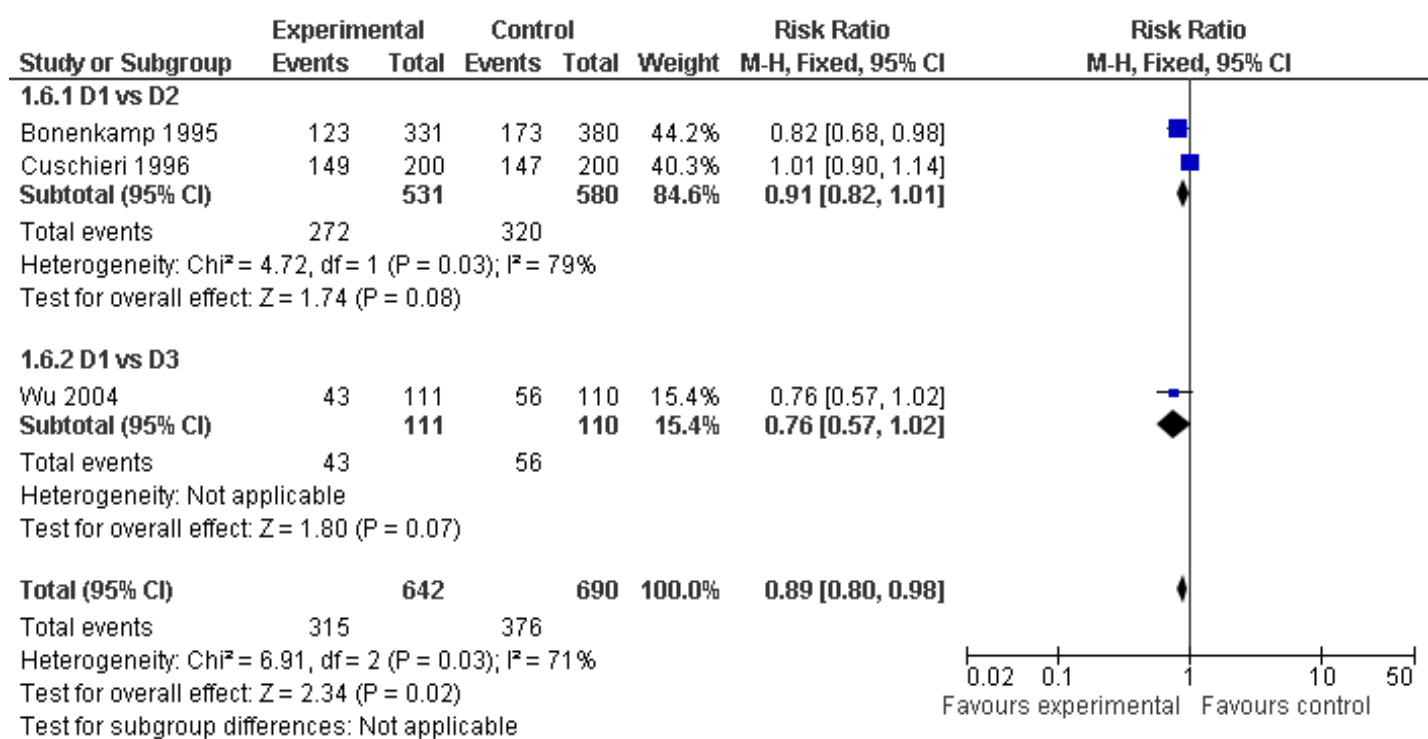

FIGURE 6 - Meta-analysis of recurrence. Effects estimates (odds ratio; 95\% CI). Pooled treatment effect is shown as a diamond that spans the $95 \%$ CI. Significant statistical heterogeneity between studies results. Overall effect with statistically significant difference favoring D2 or D3 lymphadenectomy $(\mathrm{p}=0.02)$ 


\section{Mortality with recurrent disease}

Mortality with recurrent disease, which was analyzed in 4 studies that included 1387 patients, of whom 531 D2 vs 580 D1 and 141 D3 vs 135 D1 patients, showed a no significant difference in the $\mathrm{D} 2(\mathrm{RR}, 0.89 ; 95 \% \mathrm{CI}, 0.77$ to $1.01 ; \mathrm{p}=0.08)$ with statistical data heterogeneity $\left(\mathrm{P}=0.14, \mathrm{I}^{2}=54.8 \%\right)$ and a no significant difference in the D3 lymphadenectomy group (RR, 0.83; 95\% CI,
0.62 to $1.12 ; \mathrm{p}=0.23)$ with statistical data heterogeneity $(\mathrm{P}=0.06$, $\left.\mathrm{I}^{2}=72.8 \%\right)^{5,12,13,15}$.

The overall effect estimate of 672 D2/D3 versus 715 D1 patients revealed significantly higher mortality with recurrent disease rate (RR, $0.88 ; 95 \% \mathrm{CI} ; 0.78$ to $0.99, \mathrm{p}=0.04)$ with significant statistical data heterogeneity $\left(\mathrm{P}=0.10\right.$ and $\left.\mathrm{I}^{2}=51.8 \%\right)$. The meta-analysis result from this outcome measurement is shown in Figure 7.

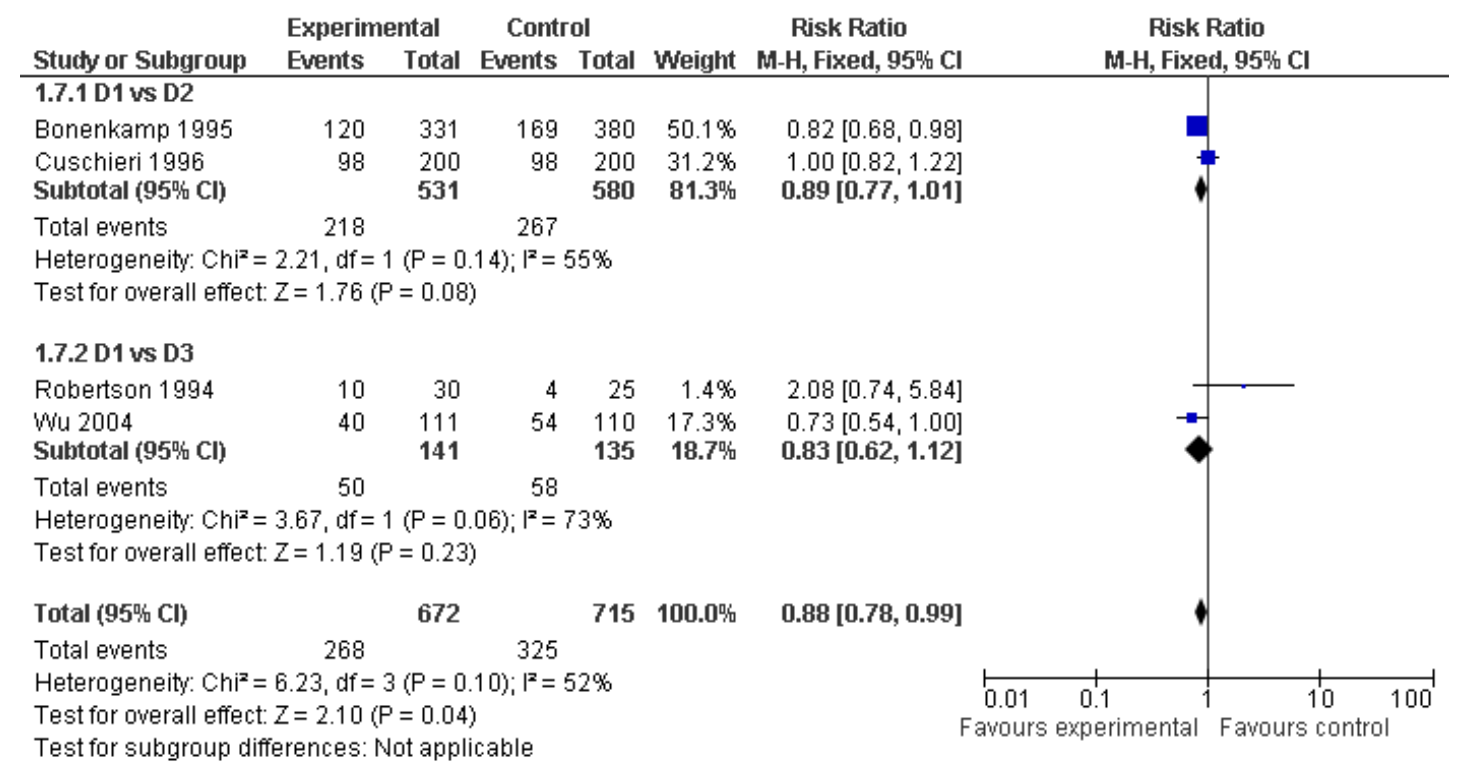

FIGURE 7 - Meta-analysis of mortality with recurrence. Effects estimates (odds ratio; 95\% CI). Pooled treatment effect is shown as a diamond that spans the $95 \%$ CI. Significant statistical heterogeneity between studies results. Overall effect with statistically significant difference favoring D2 or D3 lymphadenectomy $(\mathrm{p}=0.04)$

\section{5-year survival rate}

5-year survival rate, which was analyzed in 4 studies that included 1387 patients, of whom 531 D2 vs 580 D1 and 141 D3 vs 135 D1 patients, showed a no significant higher difference in the D2 (RR, $1.00 ; 95 \% \mathrm{CI}, 0.87$ to $1.16 ; \mathrm{p}<0.97)$ with no statistical data heterogeneity $\left(\mathrm{P}=0.34, \mathrm{I}^{2}=0 \%\right)$ and a no significant difference in the D3 lymphadenectomy group (RR, $1.24 ; 95 \%$ CI, 0.98 to $1.56 ; p=0.08$ ) with statistical data heterogeneity $\left(\mathrm{P}=0.07, \mathrm{I}^{2}=68.9 \%\right)^{5,12,13,15}$.

The overall effect estimate of 672 D2/D3 versus 715 D1 patients revealed no significant 5 -year survival rate (RR, 1.05 ; $95 \% \mathrm{CI}$; 0.93 to 1.19 , $\mathrm{p}=0.40$ ) with no significant statistical data heterogeneity $\left(\mathrm{P}=0.12\right.$ and $\mathrm{I}^{2}=$ $49.1 \%$ ). The meta-analysis result from this outcome measurement is shown in Figure 8.

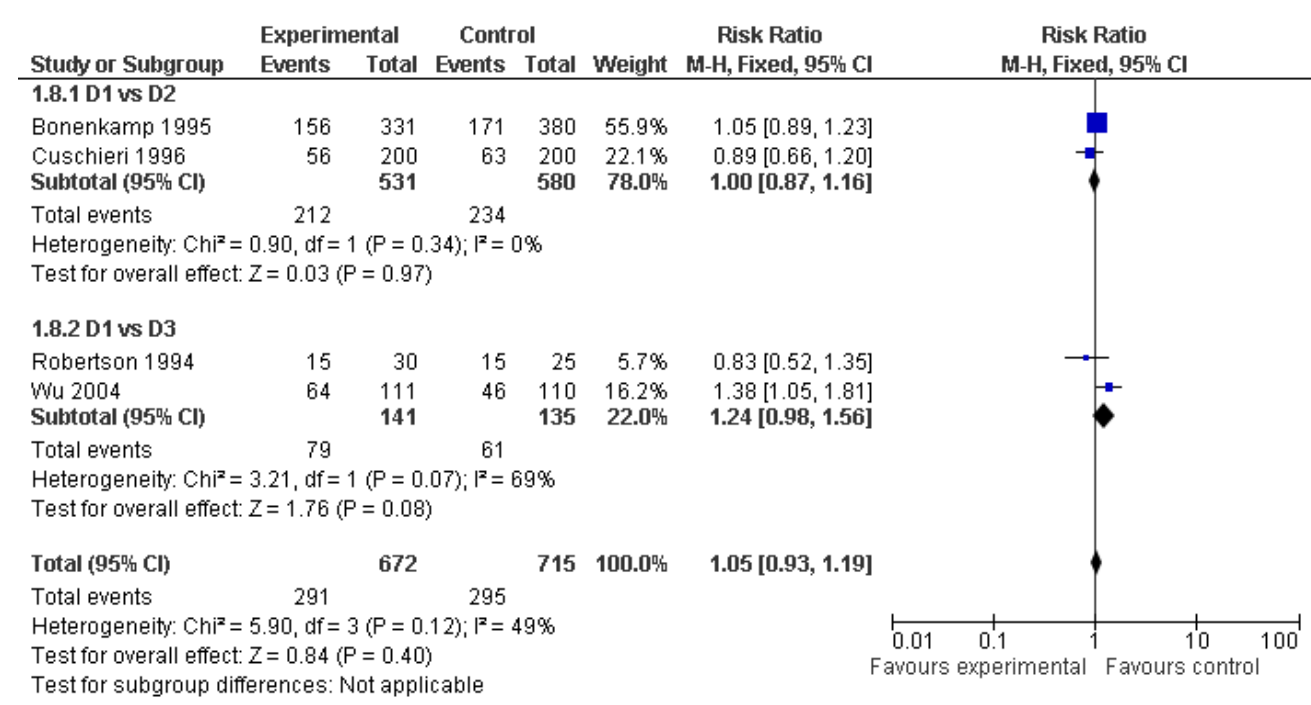

FIGURE 8 - Meta-analysis of 5-year survival. Effects estimates (odds ratio; 95\% CI). Pooled treatment effect is shown as a diamond that spans the $95 \%$ CI. No significant statistical heterogeneity between studies results. Overall effect with no statistically significant difference between D1 and D2 or D3 lymphadenectomy $(\mathrm{p}=0.40)$ 


\section{Discussion}

Systematic review and meta-analysis provide an accurate scientific tool for screening the best available evidence in the medical literature, but methodological quality of the primary studies is essential in order to obtain reliable conclusions about the overall effect of the interventions. To avoid distortions we decided only to accept the results from studies with clinical and statistical homogeneity.

One possible source of bias could lie in the differences between the randomization processes in the included studies. However, the quality of the allocation procedure was regarded as very good in all studies but one, in which the randomization procedure was considered adequate. All the patients analyzed had definite eligibility criteria. In the statistical analysis, the sample size calculation and intention-to-treat rule were used. Standard definitions for outcome parameters, standardization of surgical procedures and standardization of pathological examinations were described in all studies.

When we compared participants' characteristics between the studies, we noted that there was an adequate balance between the TNM I, II and III groups that underwent D1 versus D2 or D3 lymphadenectomy. However, clinical heterogeneity between studies may have been a source of bias, with the inclusion of a small number of patients with TNM staging IV and $\mathrm{X}$ in two studies ${ }^{5,15}$.

We decided to use the random effects model to calculate the meta-analysis, considering the possible implicit sources of clinical and methodological heterogeneity between the studies, and also because this provides wider confidence intervals, which are therefore thought to be more realistic.

The literature search strategy implemented showed that very few randomized controlled trials comparing the results between D1 and D2 or D3 lymphadenectomy for gastric cancer are available. Even though no clear benefit has so far been shown, some investigators have pursued a supposed optimum extent of surgical intervention, as in the recently reported evaluation of the possible benefits of extended D2(+) para-aortic lymphadenectomy in patients with potentially curatively resected gastric cancer ${ }^{18,19,20,21,22,23,24}$.

The clinical trials by the UK Surgical Cooperative Group ${ }^{3}$ and the Dutch Gastric Cancer Study Group ${ }^{4}$ showed high rates of postoperative morbidity and mortality, which may have negatively affected the outcome measurements of safety and efficacy ${ }^{18}$. In fact, the results from these meta-analysis have confirmed that the findings from those trials concerning morbidity and mortality can be formally accepted. The notion that mortality rates have been greatly reduced, based on the results from recent clinical trials on the surgical treatment of gastric cancer and that extended lymph node resection can be performed safely in experienced centers is unlikely to be valid $6,14,16,17,19$

Because of the complexity of extended lymphadenectomy, substantial morbidity and mortality has to be expected, even when the procedure is done by well-trained and experienced surgeons who work in hospitals that treat many patients with gastric cancer ${ }^{17}$. In order to minimize the morbidity and mortality rate, other factors involved, such as the patients' ages, general physical condition, comorbidities, operation time and tumor stage, cannot be disregarded.
Analysis of the subset of results from the Surgical Cooperative Group ${ }^{3}$ and Dutch Gastric Cancer Group ${ }^{4}$ trials indicates that the higher morbidity in the D2 group is due not to the extended lymphadenectomy but largely to pancreatic resection and splenectomy. Thus, the possible reasons for the adverse effects of pancreaticosplenectomy could be subclinical leakage of pancreatic juice, vascular impairment of the stomach remnant following proximal ligature of the arterial pedicles, and extensive clearance of tissue and lymph nodes in the gastric bed ${ }^{13}$. The question that remains is if the complications related to removal of the spleen and pancreas are excluded is there a real difference in morbidity/mortality from the D2 dissection. Unfortunately these data are not available for analysis.

The increased morbidity and mortality rates preclude the association of pancreatectomy to D2 lymphadenectomy, unless there is local involvement of the pancreas. Preserving the spleen in order to avoid increasing the incidence of morbidity and mortality leads to insufficient clearance of the lymph nodes along the distal splenic artery and splenic hilum in patients with proximal tumors ${ }^{3}$. Some authors have emphasized that pancreatic resection should be done in gastric cancer cases with local involvement and splenectomy only for proximal gastric tumors ${ }^{1,18}$.

Our meta-analysis results showed that D2 or D3 lymphadenectomy has a statistically significant relative risk of in-hospital mortality of 2.13, when compared with D1 lymphadenectomy, in five randomized clinical trials with no clinical and statistical heterogeneity that address this question and are of good methodological quality ${ }^{5,12,13,14,15}$.

Likewise, our meta-analysis results also showed also that D2 or D3 lymphadenectomy has a statistically significant relative risk of 1.98 of overall morbidity, when compared to D1 lymphadenectomy, in five randomized clinical trials with no clinical and statistical heterogeneity that address this question and are of good methodological quality ${ }^{5,13,14,15}$.

Concerning quantitative outcome measurements related to the operating time, number of reoperations and length of hospital stay, the meta-analysis results showed statistically significant differences in all rates, favoring the D1 lymphadenectomy procedure. The overall morbidity data were consistent with these meta-analysis results for these continuous outcome measurements.

If it is considered that in the west world approximately half of the patients treated by curative gastrectomy will die from residual or recurrent local disease extended lymphadenectomy for treating gastric cancer could be a rational policy, since theoretically it could lead to reduction of bed recurrence by locally controlling the cancer ${ }^{5,25}$. However, the clinical trials of the UK Surgical Cooperative Group ${ }^{3}$ and the Dutch Gastric Cancer Study Group ${ }^{4}$ failed to show any improvement in the postoperative recurrence rates when D1 and D2 lymphadenectomy were compared. In these trials, there was a tendency towards lower cumulative risk of relapse after D2 dissection, but the rate of relapse remained high.

In our study, the meta-analysis of recurrence rate was calculated based only on three randomized controlled trials, two $\mathrm{t}^{3,4}$, comparing D1 vs. D2 and one ${ }^{12}$ comparing D1 vs. D3. Although a significantly higher difference between the recurrence rates was found after the D1 procedure when compared to D2 or D3, 
there is a great deal of statistical heterogeneity in the studies. Furthermore, the results from D1 vs. D3 are based on a small number of events that were analyzed in just one study that also failed to show any statistically significant difference in the recurrence rates between the groups. Under these circumstances the meta-analysis results must be interpreted with cautiousness. Similarly, the mortality rate due to recurrence was significantly higher in the D1 lymphadenectomy group, but with significant statistical heterogeneity among the data of 4 randomized controlled trials $\mathrm{s}^{4,5,12,13}$.

Based on the results from our meta-analysis, the overall effect for 5-year survival rate did not show any statistically significant difference when D1 was compared to D2 or D3 lymphadenectomy, using data from 4 studies with no significant statistical heterogeneity among them. In contrast with the trials from the UK, Netherlands and Hong Kong, in 2006, showed that D3 lymphadenectomy had a significant long-term survival benefit over D1 lymphadenectomy, by comparing 111 and 110 patients respectively with each treatment $t^{4,5,12,13}$. The same authors had shown previously that D3 lymphadenectomy can be performed with acceptable morbidity. These results must also be interpreted cautiously and, unless patients are selected and included properly in randomized controlled trials, these results should not be accepted in general practice.

The question posed by Bonenkamp et al. ${ }^{12}$, in 1995, i.e. whether extended D2 lymphadenectomy with postoperative morbidity and mortality rates twice those of the standard D1 lymphadenectomy technique should be accepted as general practice, if no long-term benefit in survival rate has been demonstrated, cannot be answered yet due to lack of good scientific evidence on this specific issue.

Overall survival rates after radical gastric cancer surgical treatment from Western and Japanese institutions differ substantially. As reported in the literature, the migration of the disease into a more advanced stage by demonstrating lymph nodes metastases that remain unidentified when conventional surgical treatment and pathologic techniques are applied, significantly affects the nodal staging ${ }^{26}$. Recent randomized clinical trials have demonstrated confounding effects related to extended lymphadenectomy on stage-specific and overall survival. As systematic extended lymph nodes dissection induces important staging migration, the presumed benefits of extended lymphadenectomy, in terms of survival rates, still remains to be evaluated ${ }^{26,27}$.

The real oncological benefits from extended lymphadenectomy for treating gastric cancer, concerning recurrence and 5-year survival, still has to be proven. For the time being, we not only have to give importance to experience as a result of sustained caseload, surgical skill and case selection but also have to accept that extended lymphadenectomy may only be advantageous for surgical treatment of gastric cancer if morbidity and mortality rates can be reduced ${ }^{7,28}$. Wang et al. ${ }^{29}$ concluded that D2 dissection yields higher postoperative morbidity and mortality than D1 dissection and that standard D3 dissection can increase the overall survival when compared to D1 dissection and if splenectomy or pancreaticosplenectomy cases are involved D2 dissection can only improve the survival rate of T3 staged patients.

For gastric cancer the Japanese Research Society for the Study of Gastric Cancer (JRSGC) has strongly recommended extended lymphadenectomy, although it is still unclear, in terms of high level scientific evidence, whether this procedure improves survival or merely refines staging ${ }^{4}$. A recent reported clinical trial, at 24 japanese hospitals, comparing D2 lymphadenectomy alone with D2 procedure with para-aortic nodal dissection for gastric cancer, has shown that no improvement in the survival rate has been obtained ${ }^{30}$.

In the West patient fitness for surgery and patient obesity can prevent even the most experienced surgeons from achieving optimal lymph node dissection. Thus when a safe D2 dissection cannot be expected due to any of these factors adjuvant chemoradiotherapy might prove an adequate substitute. Different combinations of treatment should be established for each clinical circumstance and surgeons should play a key role here ${ }^{31}$.

This critical literature review has shown us that extended lymphadenectomy for surgical treatment of gastric cancer has a high cost in terms of morbidity and mortality and that it is not as successful in oncological terms as it has been presumed, when compared to the standard D1 lymphadenectomy technique. High-quality randomized clinical trials from specialized centers addressing this issue are still needed.

\section{Conclusions}

Our findings indicate that the D2 or D3 lymphadenectomy procedure for primary treatment of gastric cancer is followed by significantly higher overall morbidity and significantly higher in-hospital mortality than is the D1 standard technique; extended D2 or D3 lymphadenectomy shows significantly lower incidence of recurrence and lower mortality with recurrent disease, when analysed altogether (D1 x D2 or D3), in comparison with D1 nodal dissection, but these results are based on studies with statistical heterogeneity; extended D2 or D3 lymphadenectomy has no significant impact on 5-year survival rate.

\section{References}

1. Maruyama K, Okabayashi K, Kinoshita T. Progress in gastric cancer surgery and its limits for radicality. World J Surg.1987;11:418-26.

2. Nakajima T, Nishi M. Surgery and adjuvant chemotherapy for gastric cancer. Hepatogastroenterology. 1989;36:79-85.

3. Cuschieri A, Weeden S, Fielding J, Bancewicz J, Craven J, Joypaul V, Sydes M, Fayers P. Patient survival after D1 and D2 resections for gastric cancer: long-term results of the MRC randomized surgical trial. Br J Cancer. 1999;79:1522-30.

4. Bonenkamp JJ, Hermans J, Sasako M, van de Velde CJH. Extended lymph-node dissection for gastric cancer. N Engl J Med. 1999;340:908-14.

5. Robertson CS, Chung SCS, Woods SDS, Griffin SM, Raimes SA, Lau JTF, Li AKC. A prospective randomized trial comparing R1 subtotal gastrectomy with R3 total gastrectomy for antral cancer. Ann Surg. 1994;220:175-82.

6. McCulloch P, Niita ME, Kazi H, Gama-Rodrigues JJ. Gastrectomy with extended lymphadenectomy for primary treatment of gastric cancer. Br J Surg. 2005;92:5-13.

7. Hartgrink HH, Putter H, Bonenkamp JJ, Klein Kranenberg E, Songun I, Welvaart K, van Krieken JHJM, Meijer S, Plukker JTM, van Elk PJ, Obertop H, Gouma DJ, van Lanschot JJB, Taat CW, de Graaf PW, von Meyfenfeldt MF, Tilanus H, Sasako M. Extended lymph node dissection for gastric cancer: who may benefit? Final results of the randomized dutch gastric cancer group trial. J Clin Oncol. 2004;22:2069-77. 
8. Dent DM, Madden MV, Price SK. Randomized comparison of R1 and R2 gastrectomy for gastric carcinoma. Br J Surg. 1988;75:110-2. 9. Moher D, Cook DJ, Eastwood S, Olkin I, Rennie D, Stroup DF. QUORUM Group. Improving the quality of reports of meta-analyses of randomized controlled trials; the QUORUM statement. Lancet. 1999;354:1896-900.

10. Schulz K. Subverting randomization in controlled trials. J Am Med Assoc. 1995;274:1456-8.

11. Mahid SS, Hornung CA, Minor KS, Turina M, Galandiuk S. Systematic review and meta-analysis for the surgeon scientist. Br J Surg. 2006;93:1315-24.

12. Bonenkamp JJ, Songun I, Hermans J, Sasako M, Welvaart K, Plukker JTM, van Elk P, Obertop H, Gouma DJ, Taat CW, van Lanschot J, Meyer S, de Graaf PW, von Meyenfeldt MF, Tilanus H, van de Velde CJH. Randomised comparison of morbidity after D1 and D2 dissection for gastric cancer in 996 Dutch patients. Lancet. 1995;345:745-8.

13. Cuschieri A, Fayers P, Fielding J, Craven J, Bancewicz J, Joypaul V, Cook P. Postoperative morbidity and mortality after D1 and D2 resections for gastric cancer: preliminary results of the MRC randomized controlled surgical trial. Lancet. 1996;347:995-9.

14. Degiuli M, Sasako M, Ponti A, Soldati T, Danese F, Calvo F. Morbidity and mortality after D2 gastrectomy for gastric cancer: results of the Italian Gastric Cancer Study Group prospective multicenter surgical study. J Clin Oncol. 1998;16:1490-3.

15. Wu CW, Hsiung CA, Lo SS, Hscih MC, Shia LT, Whang-Peng J. Randomized clinical trial of morbidity after D1 and D3 surgery for gastric cancer. Br J Surg. 2004:91:283-7.

16. Degiuli M, Sasako M, Calgaro M, Garino M, Rebecchi F, Mineccia M, Scaglione D, Andreone D, Ponti A, Calvo F. Morbidity and mortality after D1 and D2 gastrectomy for cancer: interim analysis of the Italian Gastric Cancer Study Group (IGCSG) randomized surgical trial. EJSO. 2004;30:303-8.

17. Wu CW, Hsiun CA, Lo SS, Mao-Shin H, Jen-Hao C, Fen-Yau L, Wing-Lui L, Whang-Peng J. Nodal dissection for patients with gastric cancer: a randomised controlled trial. Lancet Oncol. 2006;7:309-15.

18. Kulig J, Popiela T, Kolodziejczyk P, Sierzega M, Szczepanik A. Standard D2 versus extended D2 (D2+) lymphadenectomy for gastric cancer: an interim safety analysis of a multicenter, randomized, clinical trial. Am J Surg. 2007;193:10-5.

19. Sano T, Sasako M, Yamamoto S, Nashimoto A, Kurita A, Hiratsuka M, Tsujinaka T, Kinoshita T, Arai K, Yamamura Y, Okajima K. Gastric cancer surgery: morbidity and mortality results from a prospective randomized controlled trial comparing D2 and extended para-aortic lymphadenectomy - Japan Clinical Oncology Group Study 9501. J Clin Oncol. 2004;14:2767-72. 20. Danielson H, Kokkola A, Kiviluoto T, Siren J, Louhimo J, Kivilaakso E, Puolakkainen P. Clinical outcome after D1 vs D2-3 gastrectomy of gastric cancer. Scand J Surg. 2007;96:35-40.
21. Kunisaki C, Akyiama H, Nomura M, Matsuda G, Otsuka Y, Ono H, Nagahori Y, Hosoi H, Takahashi M, Kito F, Shimada H. Comparison of surgical results of D2 versus D3 gastrectomy (para-aortic lymph node dissection) for advanced gastric carcinoma: a multi-institutional study. Ann Surg Oncol. 2006;13:659-67.

22. Yonemura Y, Wu CC, Fukushima N, Honda I, Bandou E, Kawamura T, Kamata S, Yamamoto H, Kim BS, Matsuki N, Sawa T, Noh SH. Operative morbidity alter D2 and D4 extended dissection for advanced gastric cancer: a prospective randomized trial conducted by Asian surgeons. Hepatogastroenterology. 2006;53:389-94.

23. Marreli D, Pedrazzani C, Neri A, Corso G, DeStefano A, Pinto E, Roviello F. Complications after extended (D2) and superextended (D3) lymphadenectomy for gastric cancer: analysis of potential risk factors. Ann Surg Oncol. 2007; 14:25-33.

24. Tsujinaka T, Sasako M, Yamamoto S, Sano T, Kurokawa Y, Nashimoto A, Kurita A, Katai H, Shimizu T, Furukawa H, Inoue S, Hiratsuka M, Kinoshita T, Arai K, Yamamura Y. Influence of overweight on surgical complications for gastric cancer: results from a randomized control trial comparing D2 and extended para-aortic D3 lymphadenectomy (JCOG9501). Ann Surg Oncol. 2007;14:355-61.

25. Gunderson L. Radiation therapy: results and future possibilities. Clin Gastroenterol. 1976;5:743-76.

26. Bunt AMG, Hermans J, Smit VTHM, van de Velde CJH, Fleuren GJ, Bruijn JA. Surgical/Pathologic stage migration confounds comparisons of gastric cancer survival rates between Japan and western countries. J Clin Oncol. 1995;13:19-25.

27. Yoshikawa T, Sasako M, Sano T, Nashimoto A, Kurita A, Tsujinaka T, Tanigawa N, Yamamoto S. Stage migration caused by D2 dissection with para-aortic lymphadenectomy for gastric cancer from the results of a prospective randomized trial. Br J Surg. 2006;93:1526-9.

28. Wu CW, Hsiung CA, Lo SS, Hsieh MC, Chen JH, Li AF, Lui WY, Whang-Peng J. Stage migration influences on stage specific survival comparison between D1 and D3 gastric cancer surgeries. EJSO. 2005;31:153-7. 29. Wang XF, Sun YH, Liang DJ. Clinical values of extended lymph node dissection for gastric cancer: a meta-analysis for D1 versus D2 gastrectomy. Zhongua Wei Chang Wai Ke Za Zhi. 2007;10:425-30.

30. Sasako M, Sano T, Yamamoto S. D2 lymphadenectomy alone or with para-aortic nodal dissection for gastric cancer. N Engl J Med. 2008;359:453-62. 31.Sano T. Tailoring treatments for curable gastric cancer. Br J Surg. 2007;94:263-4.

\section{Acknowledgements}

University Center of Volta Redonda (UNIFOA), Brazilian Cochrane Center and Gastroenterological Surgical Division of Federal University of Sao Paulo (UNIFESP).

\section{Correspondence:}

Delcio Matos

Rua Edison 278/61

04618-031 Sao Paulo - SP Brazil

dmatos.dcir@epm.br

Conflict of interest: none

Financial source: none

Received: June 10, 2008

Review: August 12, 2008

Accepted: September 17, 2008

\section{How to cite this article}

Lustosa SAS, Saconato H, Atallah AN, Lopes Filho GJ, Matos D. Impact of extended lymphadenectomy on morbidity, mortality, recurrence and 5-year survival after gastrectomy for cancer. Meta-analysis of randomized clinical trials. Acta Cir Bras. [serial on the Internet] 2008 Nov-Dec;23(6). Available from URL: http://www.scielo.br/acb 